\title{
Effectiveness of Rational Emotive Behavior Therapy (REBT) Group Format Therapy to Improve Student Self Concepts.
}

\author{
Riza Novilda ${ }^{1}$, Yeni Karneli ${ }^{2}$, Yarmis Syukur ${ }^{3}$ \\ ${ }^{123}$ Universitas Negeri Padang \\ *Padang-Indonesia (riza_novilda@yahoo.com)
}

\begin{abstract}
This research is motivated by (1) students prefer to have friends with certain people, (2) students who are smart but lack courage in expressing opinions, (3) students who are diligent in joining extracurricular activities but are less courageous in opinion. This study aims to examine the effectiveness of the Rational Emotive Behavior Therapy (REBT) group format in an effort to improve students' self-concepts caused by irrational thinking. This study uses the Quasi Experiment method with the design of The Non Equivalent Control Group. The subjects of the study were eighth grade students of SMP Negeri 3 Lubuk Basung (10 control groups and 10 experimental groups). The research instrument used a self-concept scale with a validity of 0.387 and a reliability of 0.870 . Data analysis using nonparametric statistics with Wilcoxon Signed Rank Test and Kolmogorov Smirnov 2 Independent Samples. The findings of the study show that the REBT approach to the effective group format to improve students' self-concepts, this can be seen from the increase in the self-concept scores of the experimental group students is greater than the control group's self-concept scores.
\end{abstract}

Keywords: Self-Concept, Rational Emotive Behavior Therapy (REBT)

How to Cite: Author 1, Author 2. Year. Title manuscript. Konselor, VV (N): pp. XXXX, DOI: 10.24036/XXXXXXXXXX-X-XX

\section{Introduction}

Individuals in the age range of 11-15 years are teenagers who are growing and developing towards an independent person. At this age adolescents grow to reach maturity, both mental, emotional, social and physical (Hurlock, 1999). Teenagers have the desire to do themselves and not depend on others. But it makes teenagers confused in facing their new world and sometimes bring teenagers into a problem of confusion. As they grow, adolescents have their own views and images about themselves, which are known as selfconcepts. 
The concept of self is an individual's evaluation of himself, an assessment or assessment of himself by the individual concerned (Respati, Yulianto, Widiana, 2006). Self-concept is a collection of ideas possessed by someone about himself, in which every teenager has different views in various fields including general self-concept, social, physical, and academic (Rinn, Plucker \& Stocking, 2010). The formation of this self-concept should have started from an early age. At the secondary school level, the individual's self-concept gradually grows, allowing teenagers to participate more in the fields they master and interact with others and behave in order to be accepted by others (Manning, 2017).

The concept of self is formed through repeated experiences and interactions. The concept of self is not innate from birth, self-concept can be influenced by factors within the individual such as suitability, courage in facing challenges, vision, skills and experience (Rasul, Nor, Rauf \& Amat, 2015). Self-concept is influenced by family (Syukur, 2012). Baldwin \& Holmes (Oktaria \& Pardede, 2008), explained that the factors forming adolescent self-concepts are parents, peers, the community, and learning. Research by Saraswatia, Zulpahiyana \& Arifah (2015) states that the factor that most influences adolescent self-concept is peers. Therefore, adolescents need to equip themselves to influence others by having a high self-concept, because if a teenager has a negative self-concept that tends to be low, it will affect his development. Positive self-concept is associated with many important aspects of life, such as academic achievement (McActhur, 2016). Self-concept will influence academic achievement (Matovu, 2014). Someone who has a high self-concept will make them more confident and optimistic in achieving the desired goals, in schools in particular have an impact on positive learning achievement (Sartika, 2017).

Anggellia's research (2012) states that students' self-concepts are in the low category. Manik, Radjah \& Triyono (2017) found that students' academic self-concepts were generally low. This can be seen by the attitude of students not happy about school, studying and reading, not proud of the results of learning, do not have time to study and do not do homework. Widiarti (2017) found that there were $49 \%$ of junior high school students in Jogjakarta City who had low social self-concept. People with negative self-concepts will easily give up before fighting and if it fails there will be two parties who will be blamed, whether it is blaming yourself (negatively) or blaming others (Potania, 2016), with problems like this then feel the use of the Rational Emotive approach Behavior Therapy (REBT) can help students improve their self-concepts.

REBT is a cognitive behavioral counseling approach that aims to understand and overcome negative emotional and behavioral problems that originate from irrational beliefs (Komalasari, 2011). Many studies on REBT approaches that are applied to students have been found effective in alleviating irrational beliefs in students. The REBT approach effectively reduces the saturation experienced by students (Anggreini, Daharnis, Karneli, 2019). The REBT approach with group settings is effective in dealing with student academic stress (Konadi, Mudjiran, Karneli, 2017). The REBT approach can lead students to improve their self-concept through the ABCDE format (Activating event, Belief, Consequences, Disputing, Effective new philosophy). Students are taught how to change irrational beliefs and manage emotions that cause low self-concepts so that they are able to improve selfconcepts. Based on the description above, this study aims to determine the Effectiveness of the Rational Emotive Behavior Therapy (REBT) Group Format Approach to Improve students' self-concepts. 


\section{Method}

This study uses a Quasi Experiment method with the design of The Non Equivalent Control Group. Subjects in this study were students of class VIII H as an experimental group and students of class VIII E as a control group, each group totaling 10 people. The instrument used was a self-concept scale with a validity of 0.387 and a reliability of 0.870 . Data were analyzed with the Wilcoxon Signed Ranks Test and Kolmogorov Smirnov 2 Independent Samples.

\section{Results and Discussion}

\section{Results}

The research data were obtained from the results of the pretest and posttest of the experimental and control group consisting of 10 people per group.

1. Description of Student's Self Concept Experiment Group and Control Group.

Based on the data obtained, the results of the study can be described before and after the treatment is given using the REBT group format approach. The following are students' self-concept scores in the experimental and control groups.

Table 1. Experimental Group Pretest and Posttest Results

\begin{tabular}{|r|c|c|c|c|}
\hline \multirow{2}{*}{ No } & \multicolumn{4}{|c|}{ Experiment Group } \\
\cline { 2 - 5 } & \multicolumn{2}{|c|}{ Pretest } & \multicolumn{2}{c|}{ Posttest } \\
\cline { 2 - 5 } & Score & Category & Score & Category \\
\hline 1 & 83 & $\mathrm{~S}$ & 110 & $\mathrm{~T}$ \\
\hline 2 & 104 & $\mathrm{~S}$ & 135 & $\mathrm{ST}$ \\
\hline 3 & 80 & $\mathrm{R}$ & 128 & $\mathrm{~T}$ \\
\hline 4 & 92 & $\mathrm{~S}$ & 133 & $\mathrm{ST}$ \\
\hline 5 & 73 & $\mathrm{R}$ & 132 & $\mathrm{ST}$ \\
\hline 6 & 126 & $\mathrm{~T}$ & 141 & $\mathrm{ST}$ \\
\hline 7 & 72 & $\mathrm{R}$ & 135 & $\mathrm{ST}$ \\
\hline 8 & 141 & $\mathrm{ST}$ & 150 & $\mathrm{ST}$ \\
\hline 9 & 72 & $\mathrm{R}$ & 108 & $\mathrm{~T}$ \\
\hline 10 & 80 & $\mathrm{R}$ & 118 & $\mathrm{~T}$ \\
\hline Total & 923 & & 1290 & \\
\hline Average & 92,3 & $\mathrm{~S}$ & 129 & $\mathrm{~T}$ \\
\hline
\end{tabular}

Table 2. Results of Pretest and Posttest Control Groups

\begin{tabular}{|c|c|c|c|c|}
\hline \multirow{2}{*}{ No. } & \multicolumn{4}{|c|}{ Control Group } \\
\cline { 2 - 5 } & \multicolumn{2}{|c|}{ Pretest } & \multicolumn{2}{c|}{ Pretest } \\
\cline { 2 - 5 } & Score & Category & Score & Category \\
\hline 1 & 120 & $\mathrm{~T}$ & 124 & $\mathrm{~T}$ \\
\hline 2 & 80 & $\mathrm{R}$ & 86 & $\mathrm{~S}$ \\
\hline 3 & 80 & $\mathrm{R}$ & 114 & $\mathrm{~T}$ \\
\hline
\end{tabular}




\begin{tabular}{|c|c|c|c|c|}
\hline \multirow{3}{*}{ No. } & \multicolumn{4}{|c|}{ Control Group } \\
\cline { 2 - 5 } & \multicolumn{2}{|c|}{ Pretest } & \multicolumn{2}{c|}{ Pretest } \\
\cline { 2 - 5 } & Score & Category & Score & Category \\
\hline 4 & 82 & $\mathrm{~S}$ & 102 & $\mathrm{~S}$ \\
\hline 5 & 86 & $\mathrm{~S}$ & 100 & $\mathrm{~S}$ \\
\hline 6 & 80 & $\mathrm{R}$ & 115 & $\mathrm{~T}$ \\
\hline 7 & 102 & $\mathrm{~S}$ & 124 & $\mathrm{~T}$ \\
\hline 8 & 125 & $\mathrm{~T}$ & 120 & $\mathrm{~T}$ \\
\hline 9 & 128 & $\mathrm{~T}$ & 122 & $\mathrm{~T}$ \\
\hline 10 & 80 & $\mathrm{R}$ & 89 & $\mathrm{~S}$ \\
\hline Total & 963 & & 1096 & \\
\hline Average & 96,3 & $\mathrm{~S}$ & 109,6 & $\mathrm{~T}$ \\
\hline
\end{tabular}

Based on Table 1, there was an increase in the average score of students' self-concept in the experimental group, the pretest score of 92.3 in the medium category, increasing to 129 in the high category. Wilcoxon Signed Ranks Test results show that the significance value obtained is 0.005 , which means there is a significant difference between the pretest and posttest in the experimental group. In the control group there was an increase in the average score of students' self-concepts, the pretest score was 96.3 in the medium category, rising to 109.6 with a high category. Wilcoxon test results show the significance value obtained is 0.025 which means there is a significant difference between the pretest and posttest in the control group. The increase in the self-concept score of the experimental group was greater than the control group.

Furthermore, improvement of students' self-concepts can be seen in the following diagram:

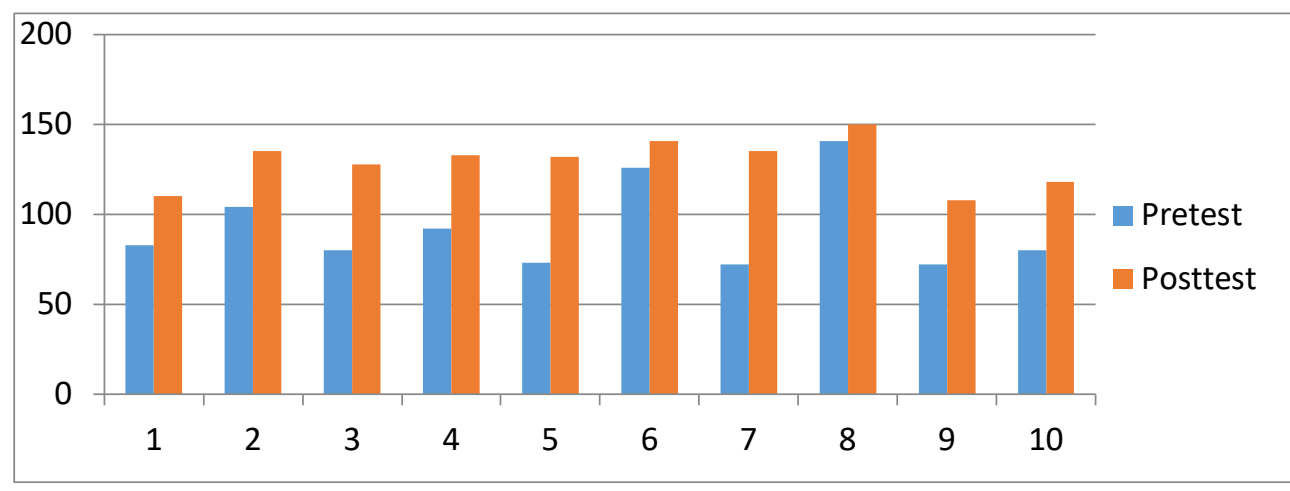

Diagram 1. Differences in Experimental Group Pretest and Posttest Results

Based on Diagram 1, there are differences in students' self-concept before being given the group format REBT approach and after being given the group format REBT approach. The diagram shows a significant increase in posttest scores of students' self-concepts in the experimental group. 


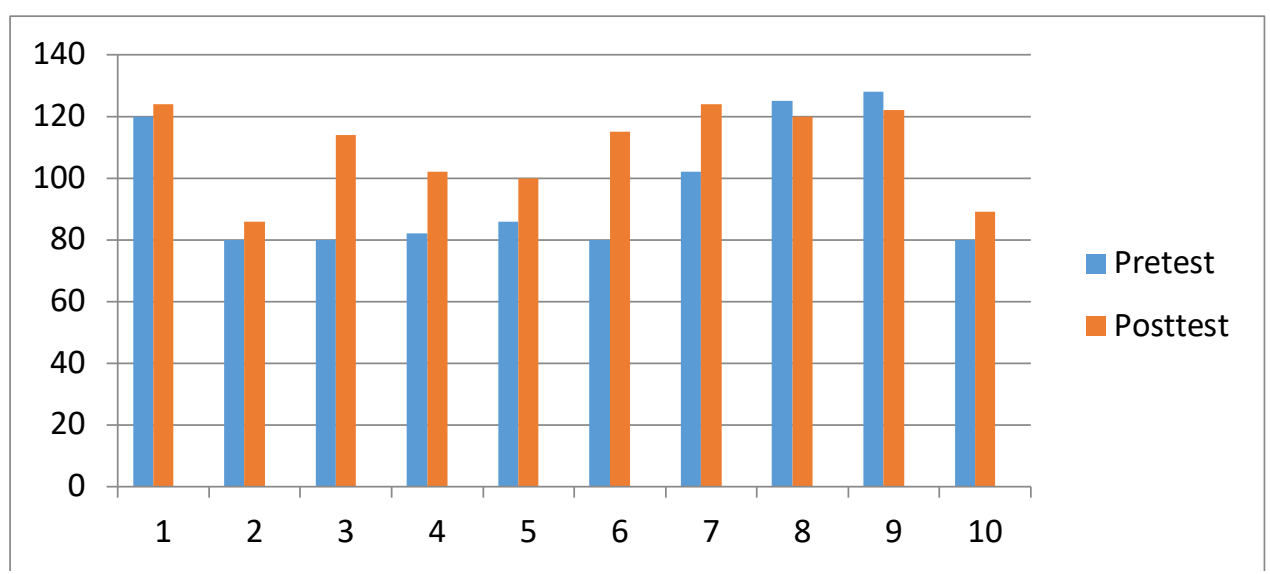

Diagram 2. Differences in the Results of Pretest and Posttest Control Groups

Based on Diagram 2, there are differences in students' self-concept before being given group format counseling without the REBT approach and after being treated. In the diagram, the students' self-concept posttest scores increased, but the increase in the experimental group was greater than the control group.

2. Experimental Group and Control Group Posttest Results

Table 2. Trial of Kolmogorov Smirnov 2 Independent Experiments and Control Groups

\begin{tabular}{|ll|r|}
\hline & & \multicolumn{2}{|c|}{ Skor } \\
\hline \multirow{3}{*}{ Most Extreme Differences } & Absolute & .700 \\
& Positive & .000 \\
Kolmogorov-Smirnov $Z$ & Negative & -.700 \\
Asymp. Sig. (2-tailed) & & 1.565 \\
\hline
\end{tabular}

Based on Table 2, the results of the posttest test of the experimental group and the control group using the Kolmogorov Smirnov 2 Independent. The student self-concept values are obtained in the Asymp column. Sig. (2-tailed) is 0.015. The significance value of 0.015 is smaller than $0.05(0.015<0.05)$. This means that the REBT approach to group formats is effective in improving students' self-concepts.

\section{Discussion}

The results of this study prove, the REBT group group approach is more effective in improving students' self-concepts. REBT approach is one of the effective strategies in improving students' self-concepts arising from irrational, negative and illogical thinking to be more rational, positive, logical and productive. REBT has a relatively simple concept to understand how aspects of our thinking can create disturbed and uncomfortable feelings, and to overcome those disturbing and uncomfortable feelings by going through the stages of ABCDE (Activating, Belief, Consequences, Disputing, Effective new philosophy ) (Palmer, 2011).

The effectiveness of the REBT approach in improving student self-concepts can be seen from the results of Noah \& Madihie's (2012) research entitled "An Application of the Sidek Module Development in REBT Counseling Intervention Module Design for Orphans". The 
results of this study prove that REBT is able to develop positive and healthy self-concepts. Gratitude-based REBT counseling can improve students' self-concepts (Sartika, 2017). Sumiroh \& Muslimin's research (2016) explains that REBT can improve students' academic self-concepts.

REBT views problematic behavior caused by irrational thinking, so the focus of handling on the REBT approach is irrational thinking experienced by students who have low selfconcepts. The results of the Thahir \& Firdaus (2017) study entitled "Improving Positive SelfConcepts of Students in Junior High Schools Using Rational Emotive Behavior Therapy (REBT) Individual Counseling, show that the low self-concept displayed is shame with different physical states, insecure, unwilling ask the teacher if you do not understand, do not dare to come to the front of the class, not able to hang out with friends and always feel different from friends.

Based on the implementation process in the activities revealed various causes of students experiencing low self-concept caused by irrational thinking. Irrational thinking possessed by group members regarding self-concept among others due to negative thoughts both on the teacher, on friends or on the subject being studied, there is a view or assumption that any effort made during the learning process does not have progress, there is a feeling of being unable and lack of confidence, whether it is not able to speak in front of the class, unable to communicate well with friends or teachers to feel afraid to be blamed, friends will laugh at their opinions, fear that they will be considered stupid and incompetent.

Self-concept and social support encourage students to get achievements in learning (Dianto, Gistituati, Mudjiran, 2015). Students who have positive self-concept will behave socially positively (Apriliyanti, Mudjiran, Ridha, 2017). The concept of self has the most dominant influence on student achievement (Fau, Firman, Mudjiran, 2016). Counseling activities using the REBT format intended to rationalize supported by previously identified thoughts.

The success of counseling using the REBT approach is also supported by the results of research conducted by Ellis (Corey, 2012), explaining that REBT can specifically be applied to group therapy and group work, giving many opportunities to reach agreement on homework, learning to challenge one's own thoughts, learning from experience other people, and interact with each other.

Teenagers and students always have irrational beliefs when something bad happens in their lives. Teenage life is very interesting to study. Given how complex the problems experienced by adolescents, especially adolescence is a transition period, physical changes that affect hormones in the body, so that emotions in teenagers begin to fluctuate. erapi is also quick to teach clients how to deal with life's problems independently. Teenagers are taught to understand themselves, to understand others, to react differently, and to change their basic personality patterns and philosophies by correcting wrong thinking. REBT approach is an approach and technique in guidance and counseling that can effectively deal with problems related to irrational attitudes and behaviors, because in this activity group members are taught how to manage negative and wrong emotions as a result of irrational thinking.

REBT can improve self-concept in adolescents (Gonzalez, Gutkin, Nelson \& Saunders, 2004). REBT-based training is able to improve the self-concept of children and teachers to prevent mental health problems and encourage positive social and emotional well-being (Casuro, Abbate, Angelone \& Ionni, 2017). REBT implementation can improve the self- 
concept of adolescents undergoing education in orphanages (Madihie, 2015). The REBT approach to group format is very useful in improving the self-concept of group members, because the REBT approach focuses more on changing students' irrational thinking about self-concepts by using cognitive, emotive, and behavioral techniques, so students can improve their self-concepts.

\section{Conclusion}

Based on the research data it can be concluded that counseling using the REBT approach to group format is very effective in improving students' self-concepts caused by irrational thoughts. This is evident from the students' self-concept scores in the experimental group experiencing a greater and more significant increase than the control group.

\section{References}

Anggellia, A. Y. (2012). Hubungan konsep diri dengan persepsi siswa tentang juvenile delinquency (kenakalan remaja) dan implikasinya dalam bimbingan dan konseling. Tesis tidak diterbitkan. Padang: PPs UNP.

Anggreini, C., Daharnis., \& Karneli, Y. (2019). The effectivenness of group rational emotive behavior therapy to reduce student learning burnot. International Journal of Research in Counseling and Education. 3 (2), 109-114.

Apriliyanti, A., Mudjiran., \& Ridha, M. (2017). Hubungan konsep diri siswa dengan tingkah laku sosial siswa. Educatio: Jurnal Pendidikan Indonesia. Vol. 2 (2). 25-29.

Caruso, C., Abbate, E., Angelone, L., \& Ionni, V. (2017). Effects of a rebt based training on children and teachers in primary school. Journal of Rational Emotive and Cognitif Behavior Theraphy. doi. 10. 1007/s10942-017-0270-6.

Dianto, M., Gistituati, N., \& Mudjiran. (2015). Kontribusi dukungan sosial dan konsep diri terhadap motivasi berprestasi siswa di smp negeri kecamatan Batang Kapas Pesisir Selatan. Konselor. Vol. 4 (1). 19-25.

Ellis, A \& Dryden, W. (1997). The practice of rational emotive behavior therapy. New York: Springer Publishing Company.

Fau, S., Firman., \& Mudjiran. (2016). Kontribusi konsep diri akademik dan motivasi terhadap prestasi belajar bahasa inggris serta implikasinya dalam penyusunan program pelayanan bimbingan dan konseling. Konselor. Vol. 5 (4). 219-228.

Gonzalez, J., Gutkin, B. T., Nelson, R \& Saunders, A. (2004). Rational emotive behavioral therapy with cildren and adolescent a meta-analysis. Journal of Emotional and Behavioral Disorders. doi. 10.1177/1063426604020040301. 
Hurlock. (1999). Psikologi perkembangan (suatu pendekatan rentang kehidupan). Jakarta: Erlangga.

Konadi, H., Mujiran., \& Karneli, Y. (2017). Efektifitas pendekatan rational emotive behavior therapy melalui setting kelompok untuk mengatasi stres akademik siswa (studi pada siswa kelas xii sma negeri 3 Padang)". Konselor 6 (4), 120-131.

Komalasari, G. (2011). Teori dan teknik konseling. Jakarta: PT. Indeks.

Madihie, A. (2015). Development and effects of psychoeducational grup interventions applying rational emotive behavior therapy and resilient therapy on self-concept among adolescents at orphanage. Researchgate. Doi. 10.13140/RG.2.1.1649.6722.

Manik, R., Radjah, L, C., \& Triyono. (2017). Rendahnya konsep diri akademik siswa smp". Jurnal Pendidikan, Vol. 2 (4), 494-502.

Manning, M. A. (2007). Self-concept and esteem in adolescents. student services. Jurnal Ilmiah.

Matovu, M. (2014). A struktural equation modelling of the academic self-concept scale. International Electronic Journal of Elementary Education. Vol 6 (2).

McArthur, G., Castles, A., Kohnen, S., \& Banales, E. (2016). Low self-concept in poor readers: prevalence, heterogeneity and risk. PeerJ 4: e2669: doi. 10 77.17.

Noah, M. S \& Madihie, A. (2012). An application of the sidek module development in rebt counseling intervention module design for orphans. ScienceDirect.. P r o c e d i a - S o cial and Behavioral Sciences 84 (2013) $1481-1491$

Oktaria, Y., \& Pardede, K. (2008). Konsep diri anak jalanan usia remaja. Jurnal Ilmiah. 1(100), 146-151.

Palmer, S. (2011). Konseling dan psikoterapi. Yogyakarta: Pustaka Pelajar.

Pontania, A. (2016). Hubungan antara konsep diri dengan gaya hidup hedonis siswa sma negeri 4 Surakarta. Doctoral disertation. Universitas Muhammadiyah Surakarta.

Rasul, S. M., Nor, M, R., Rauf, A. A., \& Amat, S. (2015). Exploring critical factors of self concept among high income community college graduates. International Education Student. Vol.8, No. 12.

Respati, W. S., Yulianto, W., \& Widiana, N. (2006). Perbedaan konsep diri antara remaja akhir yang mempersepsi pola asuh orang tua authoritarian, permissive, dan authoritative. Jurnal Ilmiah. 4(2).

Rinn, N. A., Plucker, A., Jonathan \& Stocking, B. V. (2010). fostering gifted students' affective 
development: a look at the impact of academic self-concept. teaching exceptional children plus. 6(4) Article 1.

Saraswatia, K. G., Zulpahiyana \& Arifah, S. (2015). Faktor-faktor yang mempengaruhi konsep diri remaja di smpn 13 Yogyakarta". JNKI, Vol. 3. No.1, 33-38.

Sartika, E. (2017). Konseling rational emotive behaviour therapy (rebt) berbasis rasa syukur untuk meningkatkan konsep diri remaja (studi eksperimen di mts negeri Wonokromo Pleret Bantul). Jurnal Ilmiah.

Syukur, Y . (2012). Pengaruh konsep diri dan kepuasan peran dengan upaya pemberdayaan keluarga di kecamatan Padang Utara kota Padang. Pedagogi: Jurnal Imu Pendidikan. Vol. 9 (1), 76-88.

Thahir, A. \& Firdaus. (2017). Peningkatan konsep diri positif peserta didik di smp menggunakan konseling individu rational emotive behavior therapy (rebt). Jurnal Bimbingan dan Konseling. Vol. 04 (2); 47-64.

Widiarti, P.W. (2017). Konsep diri dan komunikasi interpersonal dalam pendampingan pada siswa smp se kota jogjakarta. Jurnal Kajian Ilmu Komunikasi. Vol. 47 (1). Hal 135-148. 